STUDI

FRANCESI

\section{Studi Francesi}

Rivista quadrimestrale fondata da Franco Simone

189 (LXIII | III) | 2019

Varia

\title{
Cesare Mascitelli, Notes sur deux manuscrits de la bibliothèque des Gonzaga en 1407
}

\section{Maria Colombo Timelli}

\section{(2) OpenEdition}

1 Journals

\section{Édition électronique}

URL : https://journals.openedition.org/studifrancesi/20892

DOI : 10.4000/studifrancesi.20892

ISSN : 2421-5856

Éditeur

Rosenberg \& Sellier

\section{Édition imprimée}

Date de publication : 1 décembre 2019

Pagination : 550-551

ISSN : 0039-2944

\section{Référence électronique}

Maria Colombo Timelli, « Cesare Mascitelli, Notes sur deux manuscrits de la bibliothèque des Gonzaga en 1407 », Studi Francesi [En ligne], 189 (LXIII | III) | 2019, mis en ligne le 01 mars 2020, consulté le 11 novembre 2021. URL : http://journals.openedition.org/studifrancesi/20892 ; DOI : https://doi.org/ 10.4000/studifrancesi.20892

Ce document a été généré automatiquement le 11 novembre 2021.

\section{(c) $(1) \odot$}

Studi Francesi è distribuita con Licenza Creative Commons Attribuzione - Non commerciale - Non opere derivate 4.0 Internazionale. 


\title{
Cesare Mascitelli, Notes sur deux manuscrits de la bibliothèque des Gonzaga en 1407
}

\author{
Maria Colombo Timelli
}

\section{RÉFÉRENCE}

Cesare Mascitelli, Notes sur deux manuscrits de la bibliothèque des Gonzaga en 1407, "Romania" 136, 2018, pp. 433-442.

1 Édité en 1880 par W. Braghirolli, P. Meyer et G. Paris ("Romania" 9), l'Inventaire des livres français de la bibliothèque des Gonzaga recèle encore quelques titres mystérieux. C.M. en éclaircit deux, grâce à une analyse minutieuse des données textuelles (incipit et explicit) comparées avec les informations aujourd'hui disponibles: le «Liber plurium fabularum», qui doit correspondre à une version particulière du Bestiaire d'amour de Richard de Fournival, et un «Cretus» derrière lequel se cache, selon toute vraisemblance, une rédaction acéphale de l'Histoire ancienne jusqu'à César, «Cretus» pouvant représenter un hypocoristique pur Dictys de Crète, considéré au Moyen Âge comme l'auctoritas par excellence pour l'histoire de la guerre de Troie. 